MILITARY TECHNICAL COLLEGE CAIRO - EGYPT

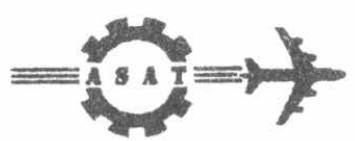

$7^{\text {th }}$ INTERNATIONAL CONF. ON AEROSPACE SCIENCES \& AVIATION TECHNOLOGY

\title{
A CONTRIBUTION TO ENGINE EMISSION CONTROL
}

\author{
H.K. HASSANEIN ${ }^{*}$
}

\section{ABSTRACT}

The problem of air pollution from engine exhaust emissions is mainly considered as a result of todays higher standard living. Emission reduction from engines is the main target now. The levels of exhaust pollutants $\mathrm{CO}$, $\mathrm{HC}$ and $\mathrm{NOx}$ are relatively high at starting and warming-up period. This paper deals mainly with this specific problem by means of heating the fresh charge directly after carburettor. This is done by means of additional heater mounted after carburettor.It depends upon the vehicle storage battary, or the like with respect to the stationary engines, as a source of electric power. The additional heater is occasionally used, according to the atmospheric temperature and at the preliminary warming-up period only.

It is found, as a result of warming up of the fresh charge, that there is an improvement in polutant levels, $\mathrm{CO} \%$ \& $\mathrm{HC}$ within a charge temperature variation range of $\left(18^{\circ} \mathrm{C}\right)$. This is due to improvement in homogenety of the mixture by good fuel evaporization. Also, as the temperature of fresh charge is increased, the fuel consumption decreased.

\section{INTRODUCTION}

There is no doubt that pollution of the air we breathe, ironically enough,

Dpartment of Mechanical Engineering, Faculty of Technical \& Industerial Education, Suez Canal University, EGYPT 
is an indirect result of our pursuit of an even higher standard of living. Air pollution derives from the burning of fuel for heating and power; from the processing of materials and disposal of wastes. Air pollution, in short, comes from those everyday activities which are an integral part of modern life, [1].

In fact, it can be said that progress has been made in emissions reduction for the internal combustion engine. This was achieved by combining the catalytic converter and the exhaust silencer and considering the engine exhaust as a system [2].

In general, it was demonistrated, with respect to petrol engines, that the levels of pollutants "CO, $\mathrm{HC} \& \mathrm{NOx}$ " are higher during starting, especially at cold starting. This requires some trials to minimize these levels of pollutants. Several research works were carried to reduce the harmfull products of engine emissions.

Also, the mixture preparation has a major influance on the ability of a carburretted engine to operate smoothly and efficiently on lean mixtures [3]. D.J. Boan and I.C. Findy [4] found that heating the manifold wall is the most effective method of achieving maximum fuel evaporation in the intake manifold for a given input of heat.

The objective of this work is to study the reducing of the engine pollutants $(\mathrm{CO}, \mathrm{HC})$ at cold starting by means of heating the admitted fresh charge directly after the carburettor, in order to avoid the drop in engine volumetric efficiency. This was done by using additional heater mounted between the carburettor and the intake manifold. This heater lessens the pollutant levels through the good fuel atomization, considerable air and fuel mixing and. as a result, complete combustion. 
electric power, which operates occasionally, i, e for two to three minutes before engine starting. This is done by using an electric circuit constructed for this purpose which switches-off the heater after the engine preliminary warming-up.

\section{2- THE EXPERIMENTAL SETUP AND MEASURING TECHNIQUE :}

\subsection{Experimental Rig :}

The schematic diagram of the experimental setup is shown in (Fig. 1 \& 2). The main parts are :

- The engine : Spark Ignition Engine., type VW, 1285 CC., 4 cylinder horizontally opposed flat, compression ratio $7.3: 1$, The engine is air cooled.

\subsection{The Design Of Fresh Charge Heater :}

A specially designed heater is made to suit the carburettor (Fig. 3), and enabls the heating of the fresh charge. It was placed around the inlet manifold after the carburettor. The heater was designed to give about 15 to $20^{\circ} \mathrm{C}$ temperature rise above the average and normal charge temperature. This rise in temperature occurs within two to three minuts by the strorage battary electric power, (through a one kilo-Ohm variable resistance).

\subsection{Other Measuring Devices}

$\mathrm{CO}$ and HC Content : Bosch exhaust-gas analyser, ETT 008.00 was used to measure the $\mathrm{CO}$ percentage in the exhaust gases. the analyzer works on the thermal abosorption principle. The heat of burning a sample from the exhaust gas causes further increase in the temperature of a filament which changes its electrical resistance and hence $\mathrm{CO}$ percentage. 
Another Bosch gas analyzer, ETT 008.12 was used to measure HC content in the exhaust gases.

Digital thermometer was used for measuring the fresh charge temperature after carburettor.

\section{THE EXPERIMENTAL RESULTS AND DISCUSSION}

3.1 Measuring Of Bollutant Levels ( $\mathrm{CO} \& \mathrm{HC}$ ) At Normal Running Without Heating

This group of tests was carried out at the ambient temperatures $(5,7$ \& $10^{\circ} \mathrm{C}$ ) and for a 94 Octane number fuel. The throttle openings were idling, with rich mixture (fuel-air ratio 1:10), the warming-up time was 10 minuts, after preheating of 2 minuts. The test results are shown in figurs $4 \& 5$. It is shown that the pllutant levels are inversely proportional to the ambient temperature. It is shown from the experimental results and figurs $4,5 \& 6$, that the engine runs in unstable condition, and gives maximum harmful emissions (especially $\mathrm{CO} \%$ ). The unperfect combustion of the mixture at these conditions is due to poor fuel evaporization and less fuel and air homogeneity after carburettor.

3.2 The Effect Of Heating The Fresh Charge (After Carburettor):

The tests are carried out at starting and slow running during the warming-up period. The fresh charge was heated to 10,14 and $18^{\circ} \mathrm{C}$ crespectively (at ambients 4,8 and $10^{\circ} \mathrm{C}$ ). The results of the effect of heating the fresh charge on the pollutant levels are shown by figurs $7,8 \& 9$. It is seen that $\mathrm{CO} \& \mathrm{HC}$ content in the exhaust, seem to decrease as the charge temperature increases. Infact, it could be attributed to the good mixture preparation of the fuel and air entering the engine cylinder as a result of the increased rate of fuel avaporation and mixture homogentey. 


\section{4- CONCLUSIONS}

The present investigation was devoted to study the effect of heating the fresh mixture-at starting-directly after carburettor on the harmfull exhaust emissions, specially $\mathrm{CO} \%$ and $\mathrm{HC}$ content .

As the temperature of fresh charge is raised, the engine performance and stability in operation were improved during ideling conditions. Also, due to good mixture preparation, the harmfule pollutants decreased. During the warming- up time, it is found that the improvement in polutant levels, $\mathrm{CO} \%$ and $\mathrm{CH}$, was within the present charge temperature variation range $\left(18^{\circ} \mathrm{C}\right)$. This is due to improvement in homogenety of the mixture by vaporizing more liquid fuel. 


\section{REFERANCES}

[1] Henery C., perkins "Air Pollution" (1974). McGraw-Hill Book Company, New York, St., Louis, San Francisco, Tokyo 407P.

[2] B. Chrisman, J.V. Serve ' Advances In Engine Emissions Control Technology" 1989 The 12th Annual Energy-sources Technology Conference And Exhibition Houston, Texas, January 22-25, (1989).

ICE-VOL.5

[3] Lester C. Lichty, "Combustion Engine Process", New York St. Lous San Franciscon, London, Kogakusha, Tokyo, (1979).

[4] D.J. Boan, And I.C. Findy, "A Computer Model Of Fuel Evaporation In The Intake System Of Carburetted Petrol Engine", National Engineering Laboratory, East Kilbride, Glargow, (1979). 


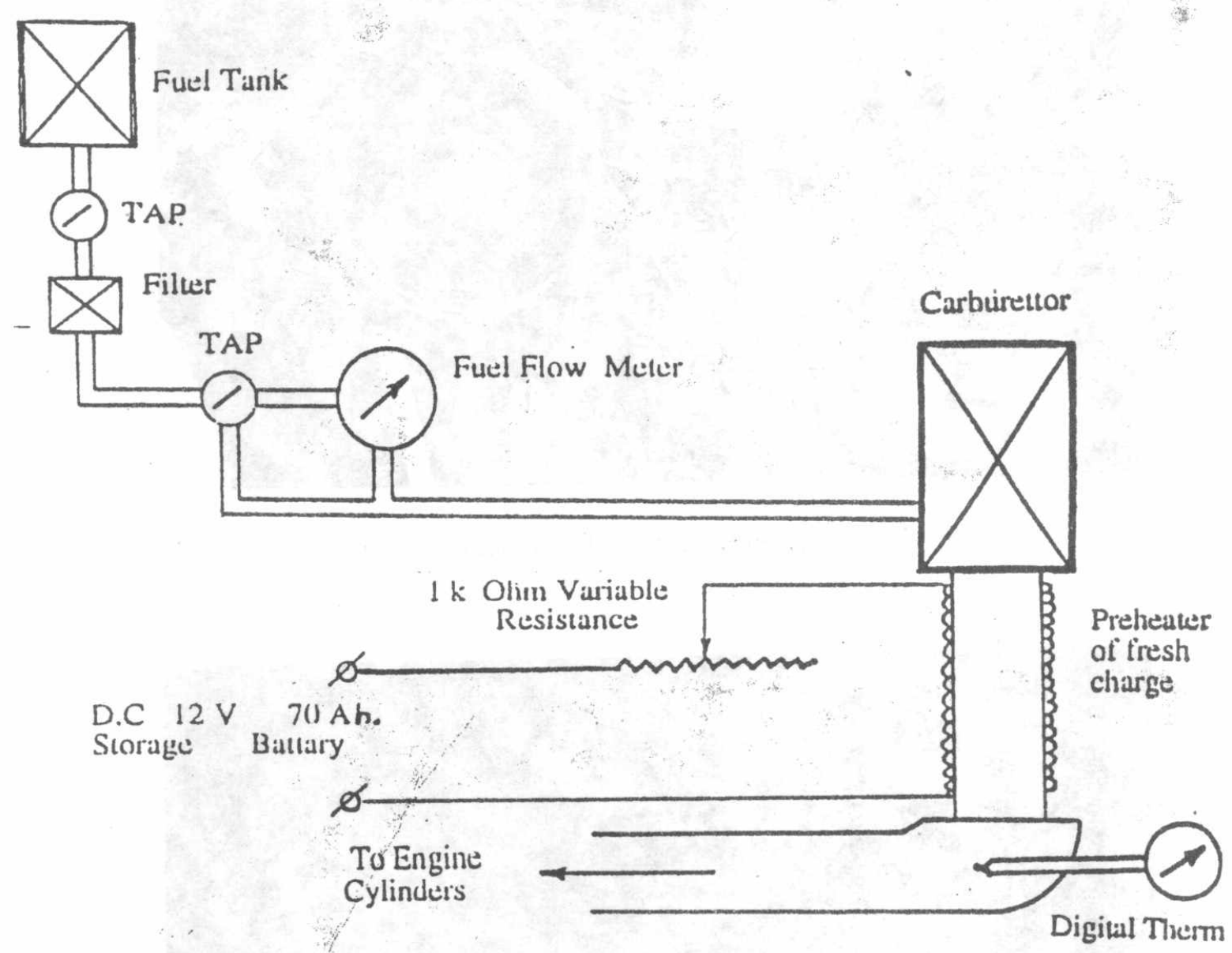

Fig. [1] Schematic Diagram of Experimental Set-up. 


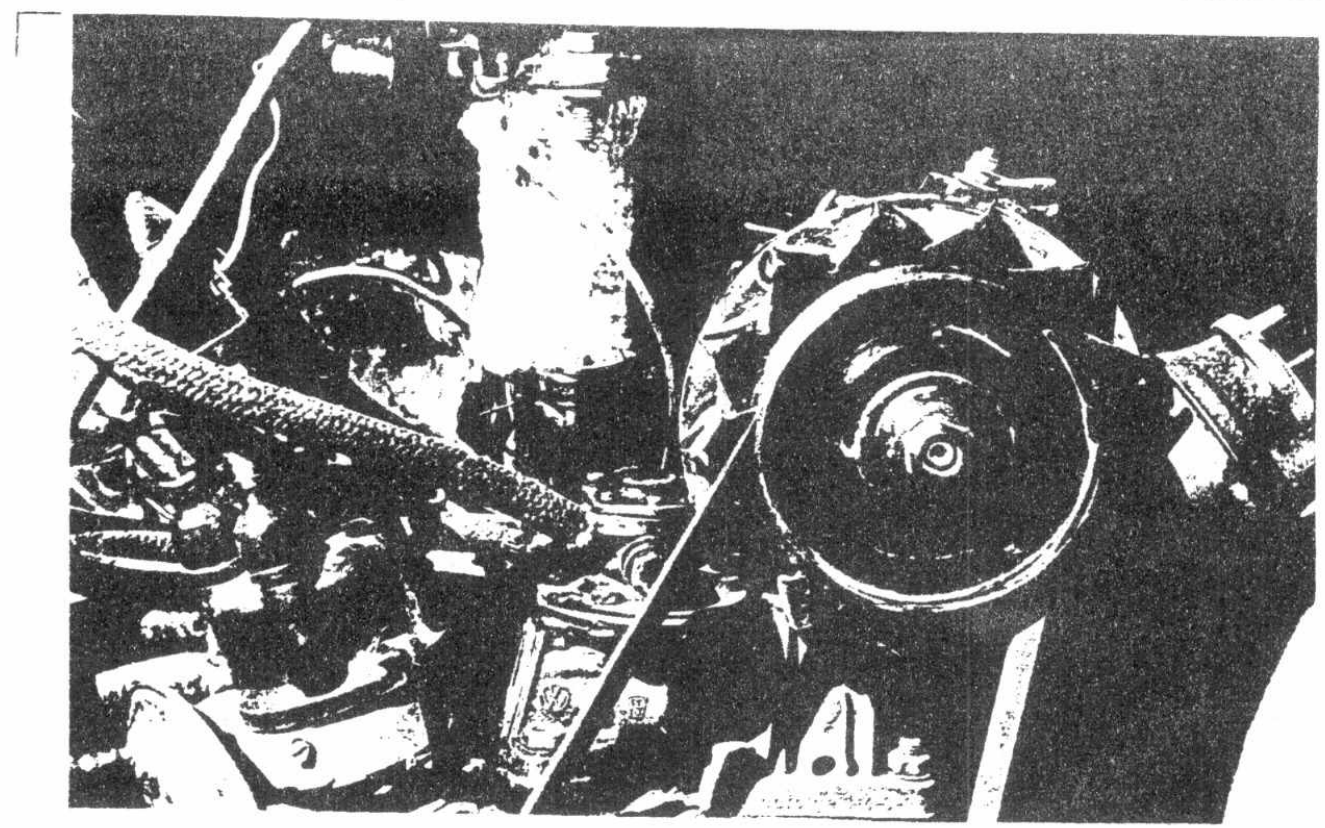

Fig. [2] Photograph of Experimental Set-up.

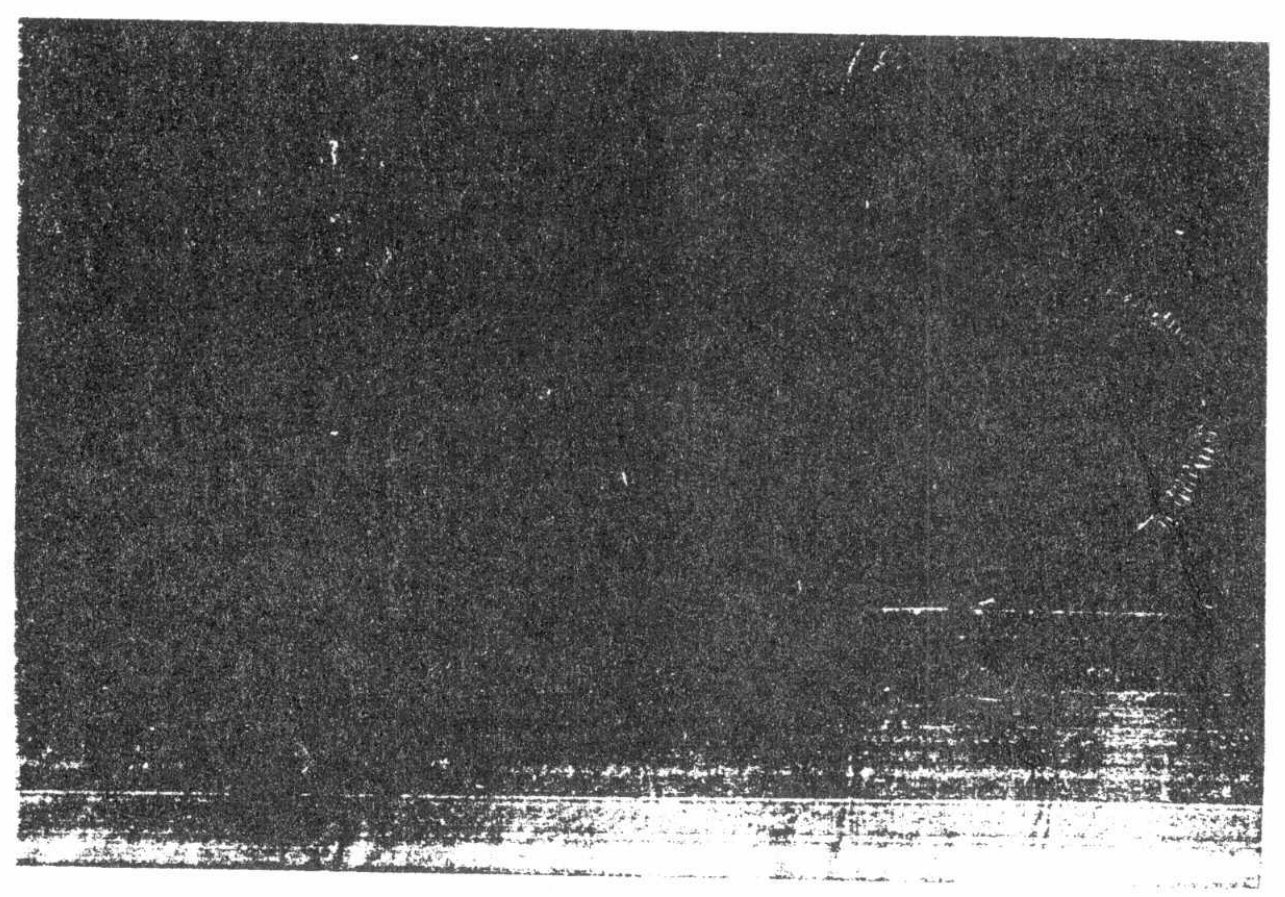

Fig. [3] Photograph of Preheater . 

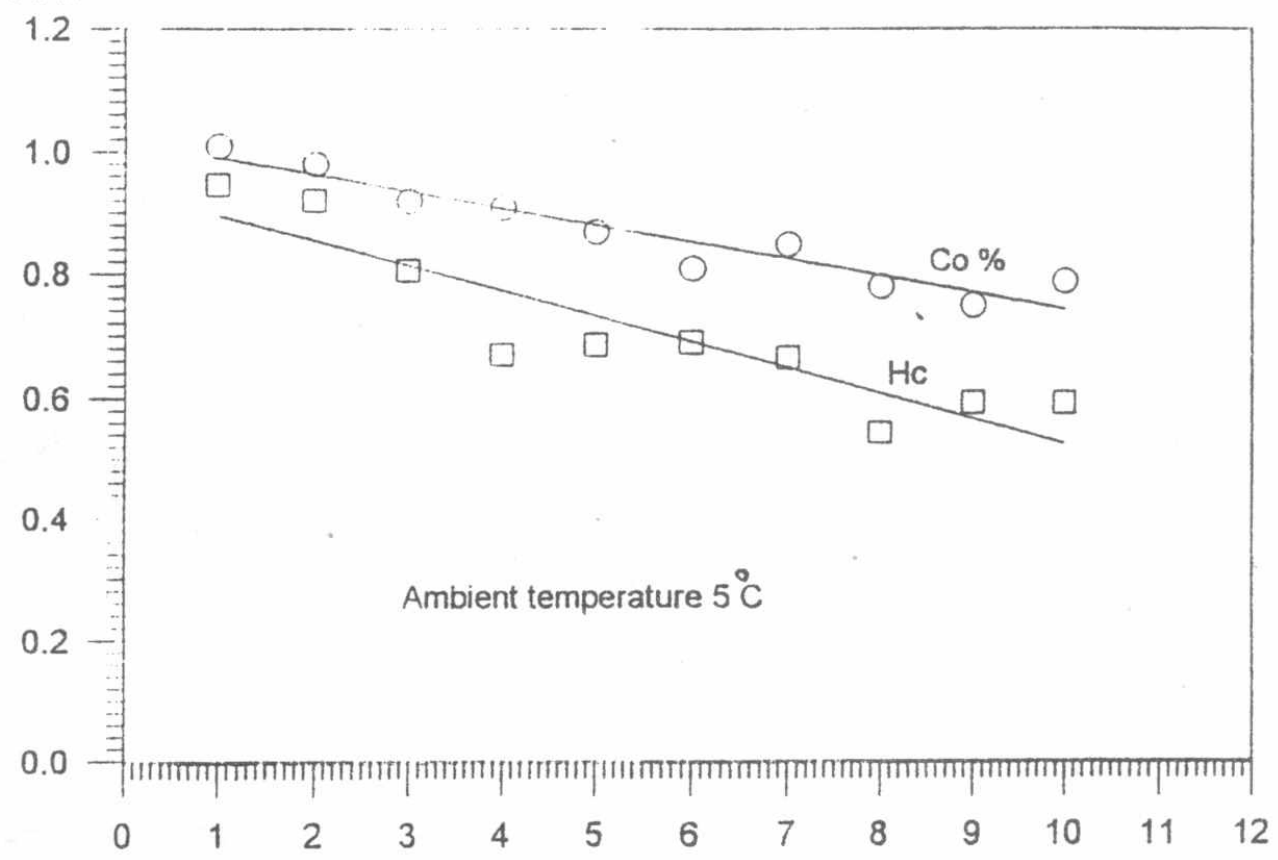

Warming - up time (min)

Fig. [4] Exhaust pollutant levels at $5^{\circ} \mathrm{C}$ ambient temperature.
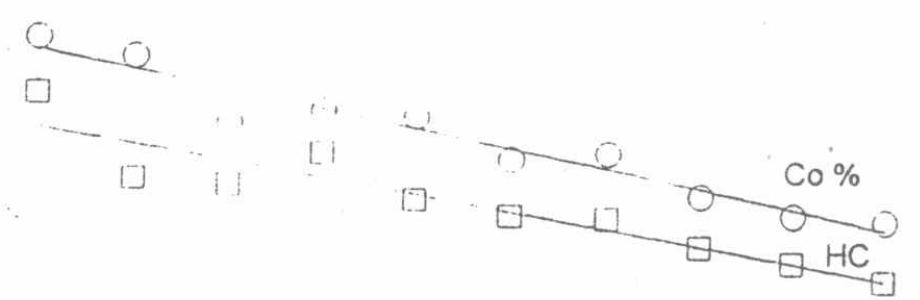

Ambient temperature $7^{\circ} \mathrm{C}$

0.2

Co $\%$

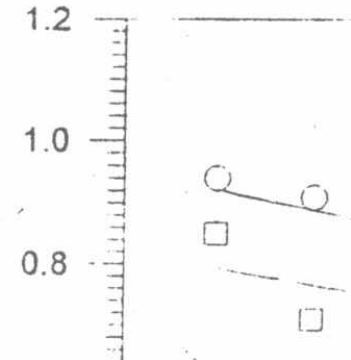

0.6

$0.4 \exists$

0.0

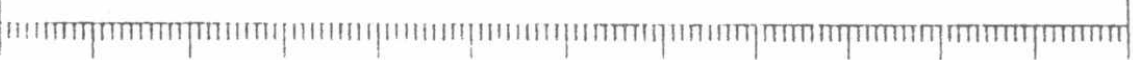

$\begin{array}{lllllllllllll}0 & 1 & 2 & 3 & 4 & 5 & 6 & 7 & 8 & 9 & 10 & 11 & 12\end{array}$

Warming - up time (min)

Fig. [5] Exhaust pollutant levels at $7^{\circ} \mathrm{C}$ ambient temperature. 


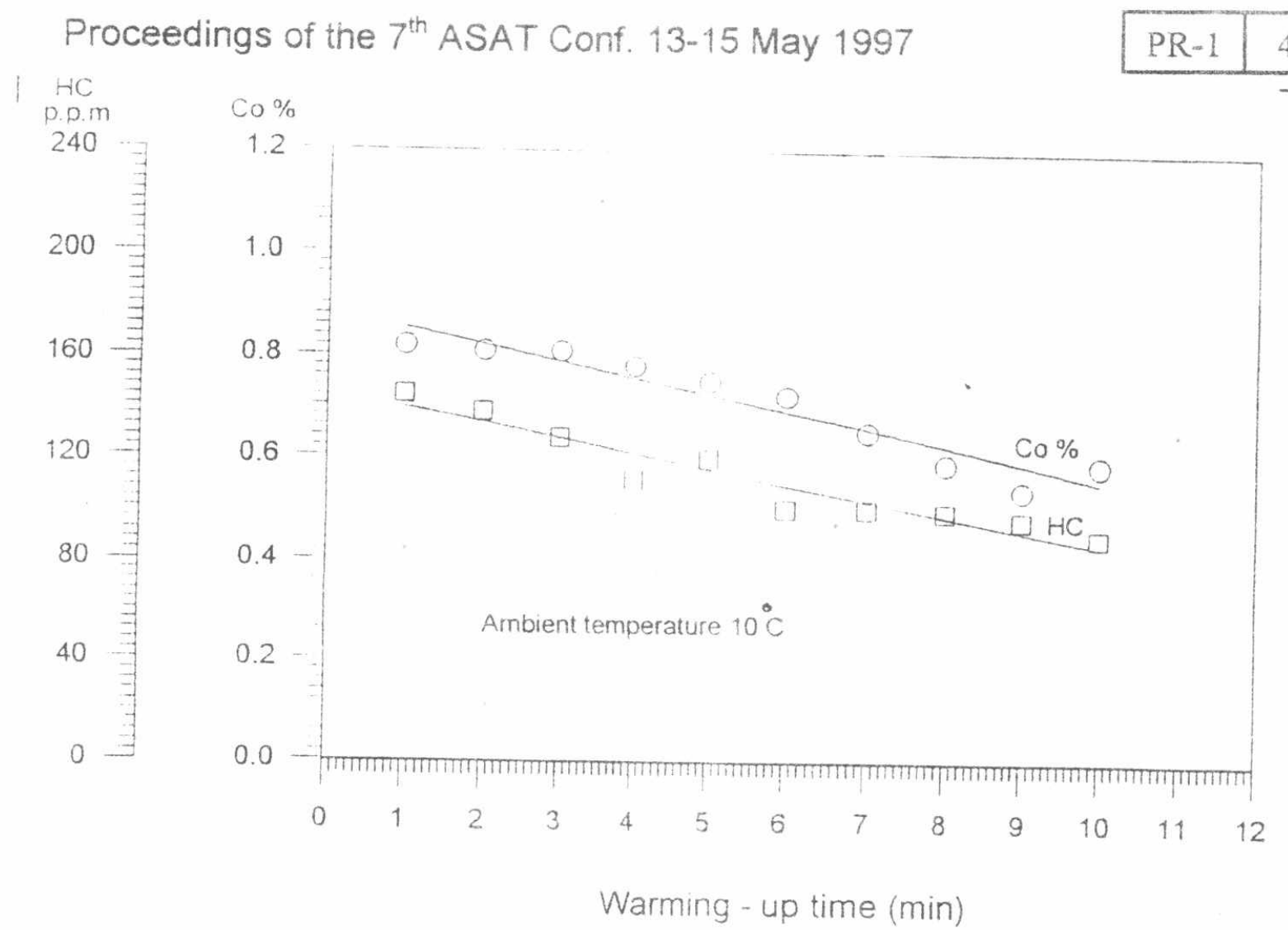

Fig. [6] Exhaust pollutant levels at $10^{\circ} \mathrm{C}$ ambient temperature.

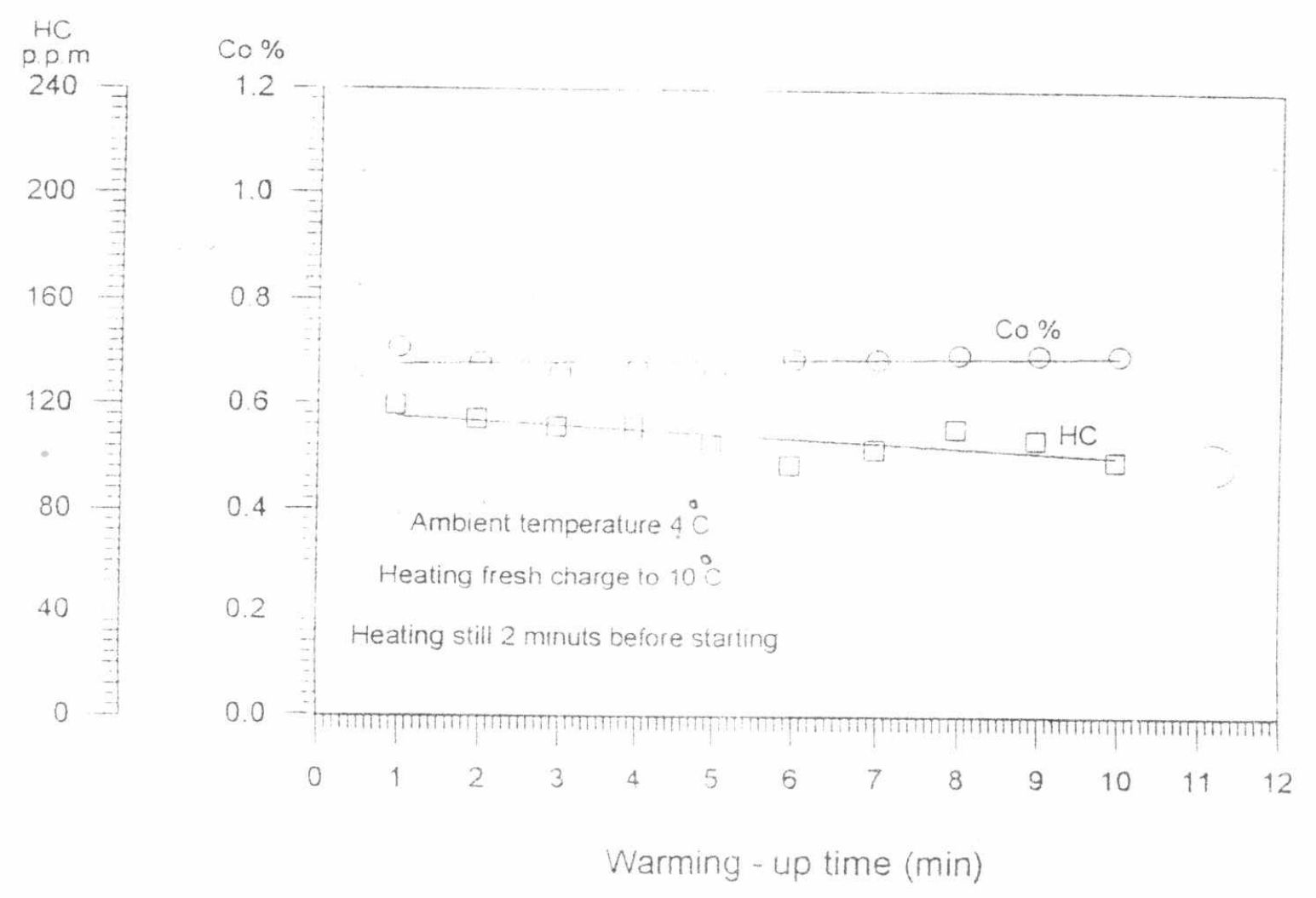

Fig. [7] Effect of fresh charge preheating on pollutant levels. 
Proceedings of the $7^{\text {th }}$ ASAT Conf. 13-15 May 1997

PR-1

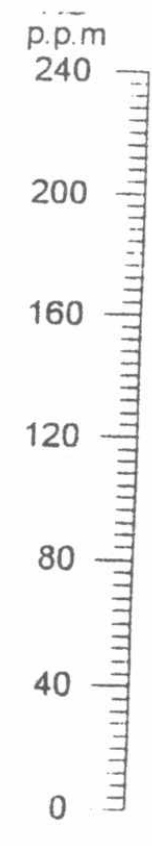

Co $\%$

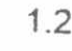

2

1.0

Ambient temperature $8{ }^{\circ} \mathrm{C}$

Heating fresh charge to $14^{\circ} \mathrm{C}$

Preheating still 3 minuts before starting

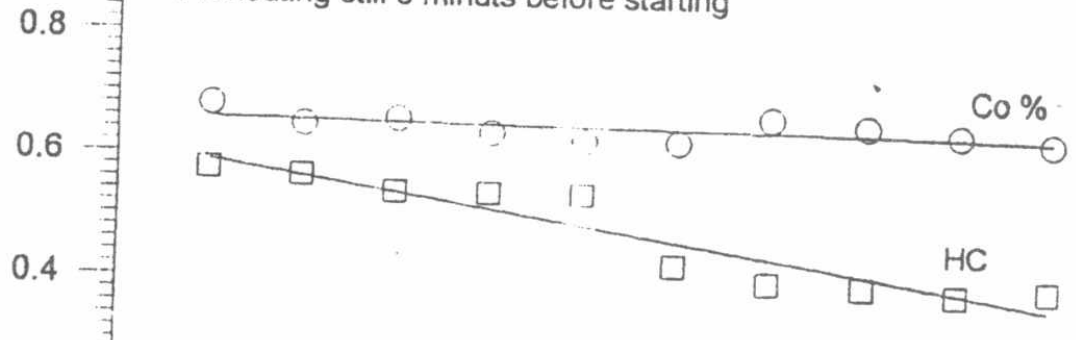

0.2

0.0

"

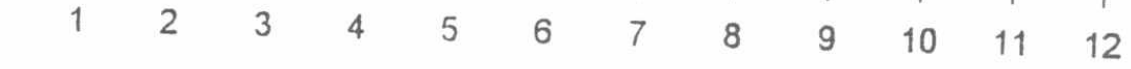

Warming - up time (min)

Fig. [8] Effect of fresh charge preheating on pollutant levels.

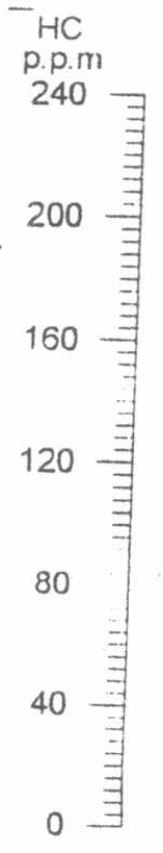

Co $\%$

1.2

1.0 Ambient temperature $10^{\circ} \mathrm{C}$

0.8 Preheating still 3 minuts befor starting

0.6 寻

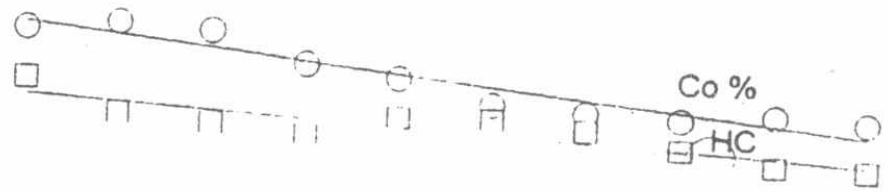

0.4

0.2

0.0

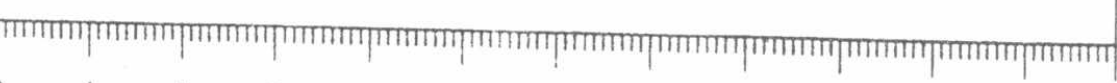

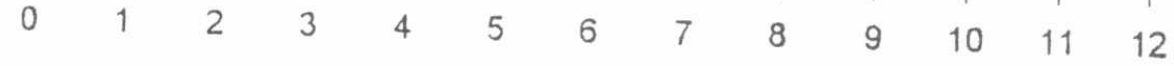

Warming - up time (min)

Fig. [9] Effect of fresh charge Preheating on pollutant levels. 